\title{
Giant Brunner's gland hamartoma!
}

\author{
Isha Verma, ${ }^{1}$ Ruchi Jha, ${ }^{2}$ Manan Parikh, ${ }^{1}$ Abhinav Agrawal ${ }^{1}$
}

${ }^{1}$ Department of Internal Medicine, Monmouth Medical Center, Long Branch, New Jersey, USA

${ }^{2}$ Department of Pathology, Monmouth Medical Center, Long Branch, New Jersey, USA

\section{Correspondence to} Dr Abhinav Agrawal, abhinav72@gmail.com

Accepted 3 June 2015

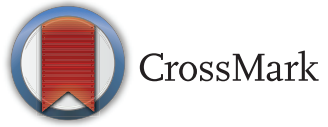

To cite: Verma I, Jha $R_{\text {, }}$ Parikh $\mathrm{M}$, et al. BMJ Case Rep Published online: [please include Day Month Year] doi:10.1136/bcr-2015210670

\section{DESCRIPTION}

A 69-year-old man, with no significant medical history, presented with weakness, fatigue and melena 4 days after knee surgery. This was not associated with nausea, vomiting or any abdominal discomfort. His medications included aspirin, statin and nonsteroidal anti-inflammatory drugs (NSAIDs) for the knee pain. His blood work revealed normocytic normochromic anaemia with haemoglobin of $6 \mathrm{~g} / \mathrm{dL}$. Physical examination and the rest of his blood chemistries were unremarkable.

Upper endoscopy showed mild oesophagitis, a few 1-2 mm non-bleeding ulcers on gastric mucosa and $10-12 \mathrm{~cm}$ long big pedunculated duodenal polyp with friable mucosa and active bleeding (figures 1-3). Endoscopically, partial polypectomy was performed owing to the size of the polyp. Biopsy of the partially resected polyp showed Brunner's gland hamartoma with low-grade dysplasia (figures 4 and 5). Therefore, laparoscopic duodenal polyp resection and pyloroplasty was performed for complete removal of the tumour.

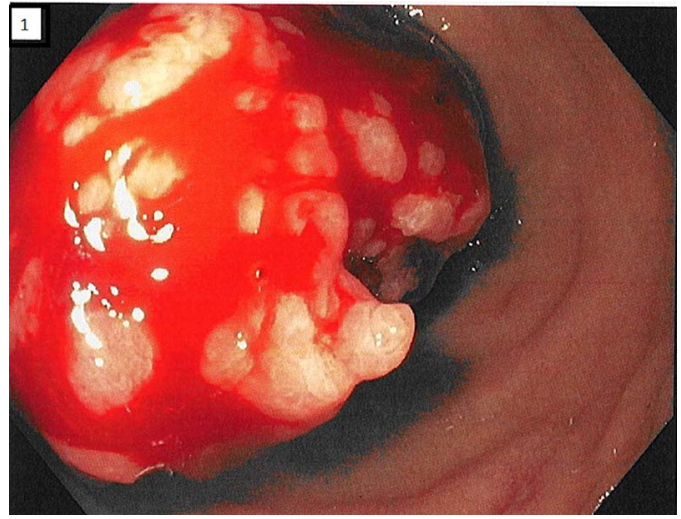

Figure 1 Endoscopic images of a giant Brunner's gland hamartoma.

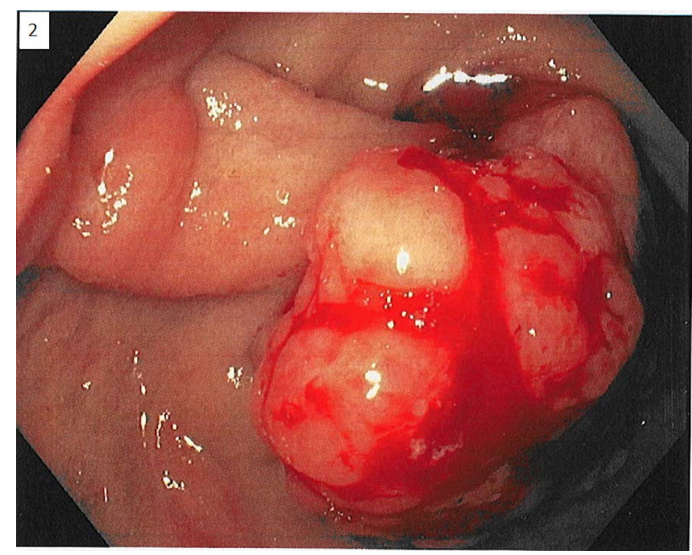

Figure 2 Endoscopic images of a giant Brunner's gland hamartoma.

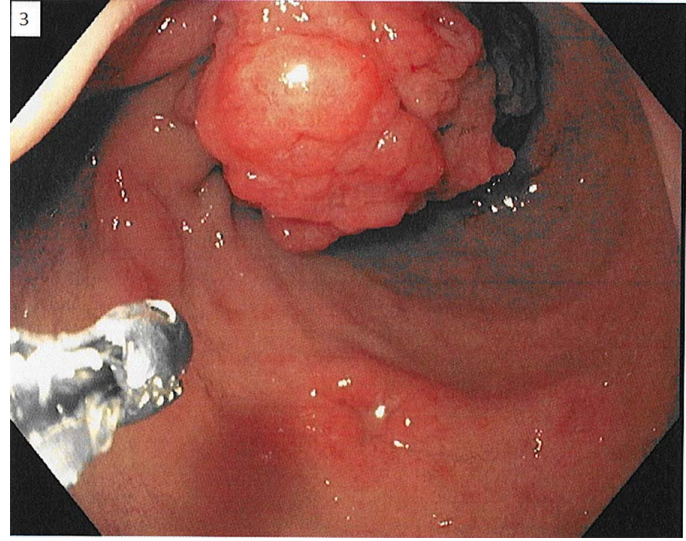

Figure 3 Endoscopic images of a giant Brunner's gland hamartoma.

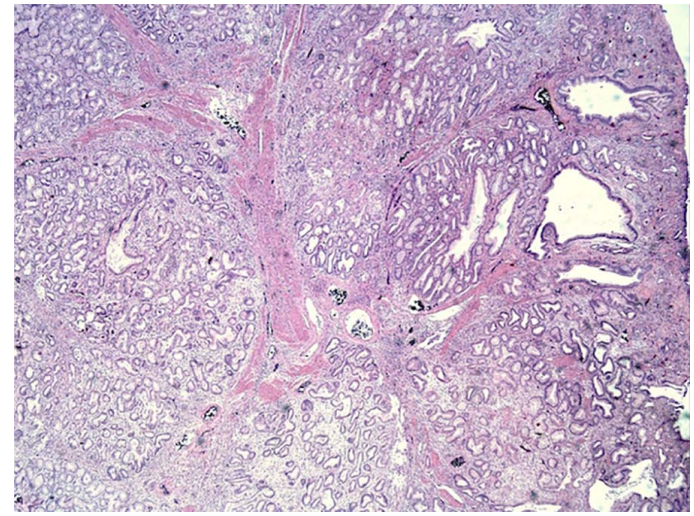

Figure 4 Histopathological image of polyp with admixture of fibromuscular and adipose tissue within and surrounding lobules of Brunner glands, few of which are cystically dilated (H\&E; ×400).

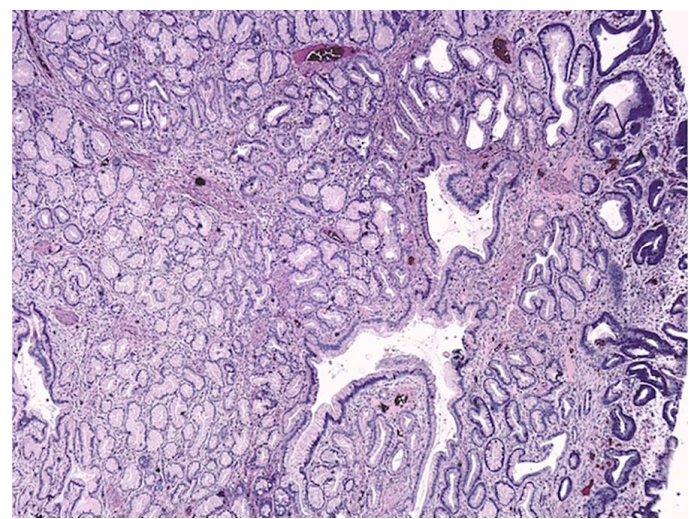

Figure 5 Histopathological image of Brunner's gland hamartoma dysplasia: focus of glands revealing nuclei with mild hyperchromaticity, increased nuclearcytoplasmic ratio and pseudostratification suggestive of low-grade dysplasia (H\&E; $\times 400)$. 
Brunner's gland adenoma, also known as Brunneroma or polypoid hamartoma, is a rare, benign, proliferative lesion arising from the acinotubular mucin-secreting submucosal glands of duodenum and accounts for $10.6 \%$ of benign tumours of the duodenum. The lesions demonstrate an admixture of normal

\section{Learning points}

- Brunner's gland hamartoma is a rare cause of first time gastrointestinal bleed, especially in the seventh decade of life.

- An increasing incidence of such lesions is seen in patients taking drugs irritating the gastrointestinal mucosa, especially non-steroidal anti-inflammatory drugs.

- These hamartomas do have a malignant potential, especially seen in tumours $>2 \mathrm{~cm}$ in size.

- It can be resected endoscopically, but large hamartomas or hamartomas with suspected malignant transformation may require surgical resection. tissues such as Brunner's glands, ducts, adipose and lymphoid tissues. Usually they are asymptomatic, but can present in the form of gastrointestinal bleed or obstruction. Precipitating factors involve any sort of mucosal irritation, including drugs such as NSAIDs. ${ }^{1}$ Endoscopic resection is the most cost-effective approach of resection. ${ }^{2}$ These tumours have a malignant potential. Surgical resection through laparoscopic approach or laparotomy is needed for complete resection in case endoscopic resection is unsuccessful and if malignancy is suspected. ${ }^{3}$

Twitter Follow Abhinav Agrawal at @re_innervated

Competing interests None declared.

Patient consent Obtained.

Provenance and peer review Not commissioned; externally peer reviewed.

\section{REFERENCES}

1 Levine JA, Burgart LJ, Batts KP, et al. Brunner's gland hamartomas: clinical presentation and pathological features of 27 cases. Am J Gastroenterol 1995:90:290-4.

2 Gao YP, Zhu JS, Zheng WJ. Brunner's gland adenoma of duodenum: a case report and literature review. Word J Gastroenterol 2004;10:2616-17.

3 Stewart ZA, Hruban RH, Fishman EF, et al. Surgical management of giant Brunner's gland hamartoma: case report and literature review. World J Surg Oncol 2009;7:68.

Copyright 2015 BMJ Publishing Group. All rights reserved. For permission to reuse any of this content visit http://group.bmj.com/group/rights-licensing/permissions.

BMJ Case Report Fellows may re-use this article for personal use and teaching without any further permission.

Become a Fellow of BMJ Case Reports today and you can:

- Submit as many cases as you like

- Enjoy fast sympathetic peer review and rapid publication of accepted articles

- Access all the published articles

- Re-use any of the published material for personal use and teaching without further permission

For information on Institutional Fellowships contact consortiasales@bmjgroup.com

Visit casereports.bmj.com for more articles like this and to become a Fellow 